\title{
China's Investment in Pakistan: Challenges and Opportunities
}

\author{
Wajeeh ULLAH ${ }^{\mathrm{a}}$, Bo YANG ${ }^{\mathrm{b},{ }^{*}}$, Hong-Fei ZHU ${ }^{\mathrm{c}}$
}

\author{
School of Economics, Zhongnan University of Economics and Law, Wuhan, 430073 China \\ a'wajeehullah100@yahoo.com, byangbo21cn@163.com, czhf930721@163.com
}

Keywords: Terrorism, Challenges and opportunities, Foreign direct investment, China and Pakistan.

\begin{abstract}
This paper investigates the challenges and opportunities in Pakistan for China's investment.Since Pakistan and China has prolonged political relationshipand connecting geographical location, the CPEC agreements was finally signed, whichprovides wide range opportunities exist for China's investors. The availability of natural resources,labor and convenient port are main opportunities for China's investmentwhile terrorismandinfrastructure are main challenges. Besides, the empirical analysis results show that determinants including investment freedom, resource endowment, interest rate and labor have positive association with China's investment to Pakistanwhile attack and trade are negatively correlated. The study suggests that Pakistan government should provide high level securities for investors in order to increase FDI inflow from China.
\end{abstract}

\section{Introduction}

Chinese companies would like to find more and more investment opportunities in Pakistan but they are facing by various challenges including terrorism, which is most serious challenge for international investors since one and half decade. Terrorism became a global issue for investors to invest in host country. Pakistan is one of the countries which are affected by this issue very badly. The international research organizations still consider Pakistan as an attractive opportunity market for China's investment in many sectors that have potential of investment. Energy, mining, infrastructure and natural resources are the main investment opportunities for investor's in Pakistan.

Most economies have a variety of restrictions on foreign direct investment, free economic policies and political conditions are the factors of investment freedom which considering loyal and friendlyopportunity for China's investors in Pakistan. Government Economic policies and Establishment policies are changing time to time but it same for China's investors in the country. Investment freedom is the basic opportunity for China's investors compare with rest of the world economies.

Sitting and operation of various projects by investors in Mining and Energy sectors for production of power and mining products in support of country GDP growth strategy have attracted more attention recently. Being their importance these two sectors has been targeted by the world investors and a major capital of investment are transferring particularly by the Chinese investors to Pakistan currently. Various investment companies show interest of investment to utilize the natural resources of mining in Pakistan but they think about the possibility of Energy and infrastructure facilities and other challenges which creating constraints in the way of investment.Chinese investment on the copper mining project, which is important natural reserve of Baluchistan province are enhancing interest of Chinese investors in mining sector in Pakistan. The exploitation of sundeck was starts from 2001 and onward (Jabeen, 2012).

Pakistan is a developing country where high population growth rate, low standard of living, low GDP growth, now this seems important to utilize the natural resources of the country to overcome the concern problems. Khan (2013) studied that Gawadar port will provide best supply chain for regional trade between Pakistan and China. China go west and Pakistan look east policies will be strengthening for trade.

Abid (2015)argued that there were various national and international challenges of investment for 
Pakistan. The government has to put these challenges on top priority. Terrorism, nationalist leaders, regional catalyst countries are the major challenges for the country.The major underlying concern challenges in the way of mining investment sector which may damaging interest of foreign investors are terrorism, energy, infrastructure, political instability, technical labor force, telecomsector, law and order situation, government economic policies, sectarian problems, conservative attitudes of general public, awareness about international investment and security problems(Imtiaz, 2011). These challenges create a threat of fear for world investors in generally and particularly for China's investors in Pakistan.

In this paper,the contribution is providing valuable information, related the present challenges and opportunities for China's investment in Pakistan. On another side this paper provides determinants correlated with China's investment to Pakistan through empirical analysis, especially to terrorism. Furthermore, the study suggests that Pakistan government should provide high level securities for investors in order to increase FDI inflow from China.

\section{The Economic Relationship between China and Pakistan}

There is a strong relationship between China and Pakistan not only in cultural, military and strategic but also in economic, trade and political sectors. Both the countries have enjoyed bilateral economic relationship since 1949. China and Pakistan economic relationship further strengthen after the settlement of Free Trade Agreement (FTA) in 2007. This trade agreement was settled in 2006 and was implemented in 2007. The aim of the agreement was to create relaxation of tariff for exports, imports and investment for both the countries in a result China and Pakistan trade was recorded in 2013 is \$12 billion dollar in which export to China was \$3 Billion and import from China was \$9 billion. The trade volume shows that Pakistan is became large importer of China's product after sign free trade agreement.

From 2001 to 2003 the trade volume between China and Pakistan just below 20 million US dollar while in the next four years it increasing and in the year 2007 and 2008 it touches the volume of 60 million US dollar but in 2009 trade volume decrease factor affecting trade volume at that stage were security issues bad governance less knowledge of trade ethics from Pakistani side onward 2009 trade volume increased and cross US \$ 16,441 million in 2015 as shown in the figure. Pakistan imported a large portion of their imports from China just shown in the table in previous current years the volume of trade rapidly goes up and occupied a major portion of trade of Pakistan compare with other trade partners of Pakistan. Major external and internal issues were raised from 2010 to 2015 which compelled Pakistan to increase the trade volume with China to decreases the dependency on other countries.

Furthermore, foreign direct investment plays an important role for economic growth in the developing countries. FDI is a key portion of determining overall growth rate of GDP. It affects the economic growth by boosting domestic investment, increasing human capital formation and introducing new technology in the host country (Schneider et al., 1985). FDI from China to Pakistan from 2001 to 2006 was not modest after signing various investment agreements the FDI grow up in 2007. The internal political situation of the country was affected FDI inflow fromChina in 2008, like various governments and opposition conflicts was the main reason of the decline. After the changing regime of the army in 2008 the political governments seriously focus on China's investment and which increased the FDI continually until 2011.

The major inflow of investment was recorded in 2011, and was declined in 2012, 2013 continually as shown in the figure. United States inflow in 2007 was recorded on top but further it was declined in various years. United states investment initially in Pakistan was favorable compare with China but after Dec-2011 it was started declining. Compared with other major investment countries, the share of China's investment in Pakistan is quite modest.

The inflow of China's investment was 35\% in 2014 and 2015 of total investment to Pakistan. Large portion of China inflow was came to Pakistan after starting CPEC project. There are 
manyinternal and external factors which affected the investment last few years but the impact of those factors on China's investment was not recorded compared with remains economies. Some polices of the government also responsible for declining the inflow of investment but internal disputes were greatly danger than external polices of the host countries. Now,the government is trying to restore the confidence of investors to continue their investment accordingly and taking serious steps like making friendly policies, introducing new technologies and making efforts to control militancy.

\section{Challenges for China's Investors in Pakistan}

Foreign direct investment is an important injecting tool for the economic development of developing countries. Since Pakistan is a developing country, the importance of foreign direct investment is same necessary for the economic growth of Pakistan. Therefore, Pakistan made serious efforts to attract an impressive foreign direct investment in the country. Economic confidence on the top priority by the government since many years to create good imagine in the mind of investors to invest in Pakistan but unfortunately it's not gained the required position in the history.

The influence of China's investment increasing very rapidly in the country but there an important question arising that is Pakistan capable to provide an adequate business environment to Chinese investors in future, currently Pakistan facing with a large number of national and international issues, which willinfluence China's investment in the future.Therefore, this is a vitol question for government as well as for the economic researcher.

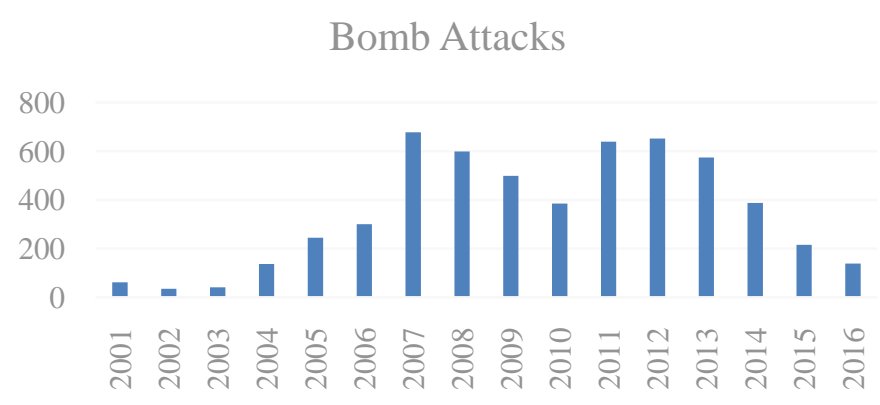

Fig.1. The number of attacks in Pakistan from 2001 to 2016.

Terrorism is most important problem which can influence the China's investment in Pakistan. Various bomb attacks during recent decade shows a serious impact over the foreign direct investment in Pakistan. Safety of capital assets and the security of China's investors are the main issue that can influence China's investment in the country. Terrorism is the burning problem currently facing every province of Pakistan. After 9/11 various companies shifted their capital to other countries, the investors describe the terrorism situation responsible for this issue. A large number of investors think negatively about the policies against war on terror in the country. Since 2001 large of personnel was engaged in business activities are targeted by the terrorist attacks in different parts of the country. An attack over China engineers which was going to Gawadar port in Baluchistan region are the serious problem which compel the government on serious thinking about the securities issues for China personnel particularly in Baluchistan where China's investment taking place rapidly.

Adequateinfrastructure facilitiesare the important ingredient after terrorism issues for attracting China's investment in Pakistan. Main Infrastructure facilities are the energy, roads, telecommunications and water system. Pakistan has no such type of facilities. Proper water systemis an important facility for life, Pakistan failed recently especially in Gawadar area to provide clear and proper water to residents of Gawadar areas. The people there protested against the government 
to provide us clear and permanent water. With the increasing activities of Gawadar port, demand of the facilities alsocontinues to increase(Malik, 2012; Perveen, 2015). Pakistan has only 30\% good roads system which compare with other Asian countries not so favorable. Pakistan has only three telecommunication companies which cannot provide services in rural areas of the country. Current age which are considering computer age Pakistan have no IT industry, neighbor developing country Indian Bangalore city have 2,000 IT companies, compare with united state less population of Pakistan have access to internet, 94\% of the people in united states have access towards internet. Energy is another important facility which Pakistan facing the problem since decade.

Skill, knowledge and attitude are playing important role for China's investors to make decision.Therefore skill labors, knowledgeable and good attitudes society are necessary in this regard. Pakistan's total population include 63\% between 18 to 40 years of youth but Pakistan until has shortage of technical labor force to attract foreign direct investment. This is important question that with the increase of China's investment in the country. Pakistan can do to provide skillful labor to the market. The answer of this question has need of long term planning. The country have no proper institutes to provide opportunities to young labor forces to gain an influential Chinese language and techniques to fulfill the demand of market in the future. Pakistan spent $2 \%$ of their budget on education which is very less amount compare with developing countries such as India and Nigeria therefore the education situation are very low in literacy ratecompared with these nations .

World becoming global village, knowledge is sharing among the national and international companies therefore need of proper knowledge to educate the people towards the market are becoming necessary. The Asian societies are mostly conservative, they cannot easily accept the custom, tradition, language, dress, food and national festivals of other societies.Therefore, it is important for the attraction of investment to change the attitudes of the people towards foreign investment. The creation of such kind environment for Pakistan in which the general people can understand the advantages of foreign investment are very important. Developed countries attitudes towards foreign investors are more flexible than developing countries. Pakistan people attitudes seem not so flexible even bureaucracy of the country so complicated that investors affected by their policies easily therefore SKA seems that can discourage Chinese investors to invest in Pakistan for long time in future.

\section{Opportunities for China's Investors in Pakistan}

In the current decade,energy is considered as engine of economic growth compare with natural resources and infrastructure. There is strong positive relation exist between energy and economic growth. Demand for energy in Pakistan increasing rapidly with the increase of population not only from the household side but from the industrial side. The average shortfall in the power sector in Pakistan is 4,000 Mega Watts, and nearly two billion cubic per day in the natural gas. Investment in the power sector has fallen to 0.7 percent of the GDP in the last 10 years, from a high of 1.5 percent during the 1980s and 1990s. The China's investors already engaged in production of energy sectors but the demand for energy more than supply and increasing with the increase of population. The China Pakistan economic corridor is considering in the country that it will turn the energy issue towards cleaner forms of energy, as China is a world leader in total wind and solar installed renewable energy, at about 140,000MW. Energy sector in investment for Chinese investors are broad and shining compare with other multinational companies on the basis of China increase investment activities in Pakistan. Turn out of investment in energy sector in Pakistan profitable more than some profitable sectors like industrial sectors.

Natural resource sector is the key sector of an economy can play Vital role in attracting an impressive foreign direct investment. Pakistan situated in the line ofnatural resource zone but unfortunately because of miss management and improper planning these resources not utilize with full capacity until now. According to an estimate west province of Pakistan Baluchistan have \$200 
billion reserves of natural resources. Proper planning is important to provide the opportunity to Chinese investors to utilize these resources. Natural resources are the main reserves of gas, oil, coal and gold which attracting foreign investors in the country. Marbles, zinc, lead and lead are the other minerals natural resources of Pakistan which is profitable for Chinese investors to invest in these sector.

Investment Freedom is the other factor that influences foreign direct investment in different ways. In an economically open and free country which there is no bans to moves the flows of investment capital is an important opportunity for investors. Investment freedom is the golden opportunity in developing countries which government creates friendly environment to attract foreign direct investment in the host country. Pakistan would like to give absolute advantages to investors from foreign countries. The establishing of such a roles which allowing the companies to transfer their resources like capital, payments, and capital transactions across border are the specific attributes of the country. There are many factors like government policies, corruption, attitudes of bureaucracy, lacking of infrastructure which influence foreign direct investment in the country. Political conditions and security conditions are the main factors which responsible for Pakistan investment freedom. For the China's investors, these factors have no impact in Pakistan, the basic reason of that is the government equal policies about the China's investors.

Interest rate is a key source of investment. Less availability of capital in the financial market and lacking of new developmental projects are the basic reason which increased interest rate in Pakistan in previously few years. Labor which is also important induced injector of foreign direct investment, Pakistan has this opportunity to attract more and more foreign direct investment in the country. A large portion of the country population contained youth which can provide cheap labor to the market. The talent of the youth can utilize to contribute GDP in different ways to enhance the skill of labor in the country. China's investors can avail this opportunity to trained the labor according to their demand of market operation.Pakistan's total population includes 63\% between 18 to 40 years of youth but until today this opportunity cannot utilized by any country or companies, China's investors can utilize this opportunity to train the labor according to their demand of skill.

\section{An Empirical Test}

The annual data has been used in this study for the year of 2001 to 2015 and compiled from variousbases sources. As the variables are time series and the dependent variable FDI cannot be determined by the independent variables at the same year, we lag the independent variables by one year. Therefore, the formula can be written as the follows:

$$
\begin{aligned}
\ln F D I_{t} & =\beta_{0}+\beta_{1} \ln R E_{t-1}+\beta_{2} \ln \text { Trade }_{t-1}+\beta_{3} \ln \text { Labor }_{t-1}+\beta_{4} \ln I_{t-1}+\beta_{5} \ln \text { Interest }_{t-1} \\
& +\beta_{6} \ln \text { Attacks }_{t-1}+\varepsilon_{t}
\end{aligned}
$$

Where the FDI means the foreign direct investment volume from China to Pakistan in the year $\mathrm{t}$ and the data used for FDI is combining sources of State Bank of Pakistan(http://www.sbp.org.pk/) and United Nation data base(http://www.unctadstat.unctad.org/En).

$\mathrm{RE}_{\mathrm{t}-1}$ means the resource endowment of Pakistan in the year $\mathrm{t}_{-1}$, which is measured by the ratio of Pakistan's export of fuels and mining products on its export of all merchandise. The source of it is World Trade Organization (https://www.wto.org/english/res_e/statis_e/).

Trade $_{\mathrm{t}-1}$ means the exports of China to Pakistan in the year $\mathrm{t}-1$ and it was taken from National Bureau of Statistics of the People's Republic of China.

Labort- 1 is the labor of Pakistan in the year $\mathrm{t}-1$ and it is from World Bank.IF $\mathrm{t}_{\mathrm{t}-1}$ means the investment freedom of Pakistan in the year t-1, which is from http://www.heritage.org/index/.

Interest $_{\mathrm{t}-1}$ means the monetary market interest rate of Pakistan in the year $\mathrm{t}-1$. State Bank of Pakistan(http://www.sbp.org.pk/) offers the data of it.

Attacks $\mathrm{t}_{\mathrm{t}-1}$ means the bomb attacks happened in Pakistan in the year $\mathrm{t}-1$ and it is from south Asia terrorism portal (http://www.satp.org/default.asp). 
Besides, because of heteroscedasticity, we estimate the model by using Weighted Least Square estimation method, the weight of the model is inverse absolute value of residuals and the heteroscedasticity has been corrected by it.

The result of descriptive statistics and correlation matrix is showed as the following table.

Table 1 DescriptiveStatistics

\begin{tabular}{llllll}
\hline & Max & Min & Mean & Median & Std. D \\
\hline FDI & 1057.000 & 1.000 & 412.710 & 223.000 & 419.146 \\
RE & 7.313 & 2.124 & 4.508 & 4.413 & 1.826 \\
Labor & 67.179 & 42.609 & 54.880 & 54.672 & 7.918 \\
Trade & 16441.89 & 815.080 & 6451.475 & 5789.050 & 4554.377 \\
Interest & 12.500 & 2.100 & 8.520 & 8.900 & 3.241 \\
IF & 50.000 & 30.000 & 42.667 & 40.000 & 7.761 \\
Attacks & 678.000 & 35.000 & 363.333 & 385.000 & 234.702 \\
\hline
\end{tabular}

The table shows the descriptive analysis the maximum, minimum,mean and median value and standard deviation. The result shows that the variables vary so much in different years. Standard deviation value shows the variables have large Standard Deviation, especially for FDI and Trade.To analyze the relationship between them, WLS model is used and the results are showed in the following table.

Table 2 WLS estimate outcomes

\begin{tabular}{c|llll}
\hline & \multicolumn{4}{|c}{ Dependent Variable: $\log (\mathrm{FDI})$} \\
\hline & Model 1 & Model 2 & Model 3 & Model 4 \\
\hline $\log (\mathrm{RE}(-1))$ & $2.6482^{* * *}$ & $3.5853^{* * *}$ & $3.6812^{* * *}$ & $4.2760^{* * *}$ \\
& $(12.3026)$ & $(9.5129)$ & $(21.2639)$ & $(12.9348)$ \\
$\log ($ Labor(-1)) & $4.5267 * * *$ & $22.3118^{* * *}$ & $21.3476^{* * *}$ & $22.9323^{* * *}$ \\
& $(5.0275)$ & $(6.4145)$ & $(13.6812)$ & $(9.9457)$ \\
$\log ($ Trade(-1)) & & $-3.3308^{* * *}$ & $-2.8746^{* * *}$ & $-3.0609 * * *$ \\
& & $(-5.8872)$ & $(-11.0635)$ & $(-7.5534)$ \\
$\log ($ Interest(-1)) & & & $0.2746^{* * *}$ & $0.3533^{* *}$ \\
& & & $(4.0329)$ & $(2.7228)$ \\
$\log (\mathrm{IF}(-1))$ & & & $3.0682^{* * *}$ & $3.1998^{* * *}$ \\
& & & $(9.3490)$ & $(10.7640)$ \\
$\log ($ Attacks(-1)) & & & & $-0.2814^{*}$ \\
& & & $-73.0041^{* * *}$ & $-77.7306^{* * *}$ \\
Constant & $-16.6400^{* * *}$ & $-60.8775^{* * *}$ & $-2.0631)$ \\
& $(-5.0851)$ & $(-6.4237)$ & $(-16.7507)$ & $(-12.6450)$ \\
R^2 & 0.9928 & 0.9791 & 0.9986 & 0.9995 \\
\hline
\end{tabular}

Notes: The symbols $* * *, * *$ and $*$ denote statistical significance at the $1 \%, 5 \%$ and $10 \%$ level respectively.

The details of WLS regression model results are presented in table 2. For all the models the value of dependent variable is in the year $t$, while all the independent variables are lagged by one year. Model 1 estimates the influence of natural factors including resource endowment and labor resource. The result shows that both of it are positively correlated with FDI from China to Pakistan. In model 2 , trade is added as a new independent variable and the results shows that the trade is negative correlated with FDI. It implies that trade between China and Pakistan has substitution effect on FDI. Model3 adds the financial factors that are interest rate and investment freedom. The regression result shows that interest rate and investment freedom are positively correlated with FDI from 
China to Pakistan. The result indicates that investment freedom is better for FDI. The higher interest rate reflects the shortage of local capital, induce the more investment opportunities. Model 4 added the attacks based the model 3 , the result shows that independent variable of attacks number is negatively correlated with FDI from China to Pakistan. It proves that terrorism has a negative effect on FDI. Terrorism damages investment environment of Pakistan, which results capital shifted to other countries.

\section{Conclusion}

This paper shows the challenges and opportunities for China's investors in Pakistan. The paper highlights various investment opportunities and challenges for China's investors in Pakistan, which can affect China's investment in the country in future. The paper also shows various sectors of the economy where special investment opportunities exist for Chinese investors. Therefore, this study tries to specify those profitable sectors of the economy where broad investment opportunities existing for Chinese investors. The study also highlights the impact of different variables on China investment in Pakistan. Since Pakistan is suffering from the issues of terrorism, political instability, energy shortage, infrastructure deficiency and government investment weak polices about foreign investment. Therefore, the other side of this paperdescribed how these issuesaffect China's investment in the future.

Our empirical result shows that terrorism attacks have a negative impact over FDI in Pakistan. Terrorism is the important concern issue which strongly inversely associated with foreign direct investment compare with other variables. The effect of attacks negatively correlated with investment in the country as terrorism increasing FDI decreasing. Since Pakistan making efforts to attract foreign investment in the country, but it may not bring a positive result. Therefore in this critical situation China's investment in Pakistan especially investment in Gwadar and CPEC projects shows great financial investment support for the poorest and down economy of Pakistan. The important purpose of this study works on another side to inform the knowledge of China's investors to highlight them opportunities of investment in Pakistan.

Further the aim of this study to suggest and recommend the government that how they can reduce the risk and uncertainty for Chinese investors to strengthen their confidencein the future. The government is recommended to take serious steps for the security purpose of Chinese personnel working in different projects in different parts of the country. The government should provide peaceful and secure investment environment to investors to run their business activities without fear and hesitation. Increased funding to security forces and trained special force to protect Chinese investors in the country. The local public involvement in employment, trade and business which would stop the people to join terrorist groups are the important suggestion for the government in this regard.

\section{References:}

[1] Abid, M., \& Ashfaq, A. (2015). CPEC: Challenges and opportunities for Pakistan. China, Pakistan One Belt Road Project. Journal of Pakistan Vision, 16(2): 142-169.

[2] Ahmad, M. H., Alam, S., Butt, M. S., \& Haroon, Y. (2003). Foreign Direct Investment, Exports, and Domestic Output in Pakistan. The Pakistan Development Review, 42(4): 715-723.

[3] Avais, M. M. A., Shaikh, M. S., Mahesar, H. A., \& Memon, M. F. (2016). China-Pak Economic Corridor: Social Analysis for Pakistan. The Government-Annual Research Journal of Political Science, 5(5): 164-171.

[4] Imtiaz, S. Y., Khan, M. A., \& Shakir, M. (2015). Telecom sector of Pakistan: Potential, challenges and business opportunities. Telematics and Informatics,32(2), 254-258. 
[5] Jabeen, M. China and EconomicDevelopment in South Asia: A Case Study of Baluchistan. Journal of the Research Society of Pakistan,53(2): 254-266.

[6] Khan, S. A. (2013). Geo-economic imperatives of Gwadar Sea Port and Kashgar Economic Zone for Pakistan and China. Islamabad Policy Research Journal, 13(2), 87-100.

[7] Malik, H. Y. (2012). Strategic importance of Gwadar port. Journal of Political Studies, 19(2): 57-69.

[8] Perveen, S., \& Khalil, J. (2015). Gwadar-Kashgar Economic Corridor: Challenges and Imperatives for Pakistan and China. Journal of Political Studies, 22(2): 351-366.

[9] Schneider, F., \& Frey, B.S. (1985). International Fedration of Shipmaster's Associations. Economic and Political determinants of foreign direct investment. World development, 13(2): 161-175. 